\title{
Desain Konsep Kapal Perang Serbu Catamaran Tank Boat dengan Sistem Penggerak Utama Turbojet sebagai Kekuatan Pengamanan Wilayah Maritim Indonesia
}

\author{
Kevin Alfinno H. B. dan Wasis Dwi Aryawan \\ Departemen Teknik Perkapalan, Fakultas Teknologi Kelautan, Institut Teknologi Sepuluh Nopember (ITS) \\ e-mail:wasis@na.its.ac.id ; aryawanwasis@gmail.com
}

\begin{abstract}
Abstrak-Indonesia merupakan negara maritim yang terbesar di dunia dengan $80 \%$ dari wilayahnya yang berupa lautan. Hal ini menyebabkan susahnya pengawasan terhadap keamanan dan kedaulatan wilayah NKRI khususnya dalam sektor maritime. Oleh karena itu dibutuhkan desain kosep kapal cepat katamaran yang baik dan cepat tanggap sebagai alusista perang dan pengamanan wilayah maritim Indonesia. Tujuan dari desain kapal Tank Boat ini adalah 1. menentukan operational requirements kapal perang serbu Catamaran Tank Boat dengan Turbojet, 2. Memperoleh ukuran utama kapal perang serbu Catamaran Tank Boat dengan Turbojet, 3. Mendapatkan lines plan dan rencana umum kapal perang serbu Catamaran Tank Boat dengan Turbojet, 4. Mendesain layout awal rencana umum dan model 3D kapal perang serbu Catamaran Tank Boat dengan Turbojet. Dalam proses desain awal kapal perang ini, dilakukan penentuan operational requirement kapal dan ukuran utama kapal yang diperoleh dari metode parent ship dengan ukuran utama $L O A=18 \mathrm{~m}, B=6,6 \mathrm{~m}, T=1 \mathrm{~m}$. Hasil akhir dari desain ini yakni operational requirement dari Catamaran Tank Boat dengan fungsi dan tugasnya sebagai Fast Patrol Boat armada pemukul bantu dan patroli penjagaan wilayah maritim Indonesia. Wilayah operasional Kapal, yakni seluruh perairan Indonesia khususnya ZTE, kecepatan maksimal kapal 55 knot, kecepatan saat pengejaran 45 knot, kecepatan patroli 25 knot. Untuk kemampuan operasional, kapal dapat beroperasi selama 148 menit dengan kecepatan 55 knot, 154 menit dengan kecepatan 45 knot dan 6,5 jam dalam operasi patroli. Hasil dari analisis teknis didapatkan ukuran utama akhir dengan LOA = $18 \mathrm{~m}, \mathrm{Lpp}=17.03 \mathrm{~m}, \mathrm{~B}=6.6 \mathrm{~m}, \mathrm{H}=2.8 \mathrm{~m}, \mathrm{~T}=1 \mathrm{~m}$ serta hasil desain Lines plan, General Arrangenment, dan 3D kapal Catamaran Tank Boat
\end{abstract}

Kata Kunci-Catamaran Tank Boat, Turbojet, kapal perang, Indonesia

\section{PENDAHULUAN}

I NDONESIA merupakan negara maritim yang terbesar di dunia dengan $80 \%$ dari wilayahnya yang berupa lautan. Luas wilayah Indonesia mencapai 7.81 juta $\mathrm{km}^{2}$ dimana 2.01 juta $\mathrm{km}^{2}$ adalah wilayah daratan maka dengan demikian luas laut territorial Indonesia mencapai 3,25 juta $\mathrm{km}^{2}$ dan luas laut perairan Zona Ekonomi Eksklusif (ZEE) mencapai 2,55 juta $\mathrm{km}^{2}$. Ditambah dengan strategisnya posisi Indonesia yang diapit dua samudera dan dua benua, dapat memicu terjadinya konflik teritorial dengan negara asing. Luasnya sektor perairan Indonesia yang mencapai $80 \%$ dari seluruh luas wilayah Indonesia, menyebabkan susahnya pengawasan terhadap keamanan dan kedaulatan wilayah NKRI khususnya dalam sektor maritim. Cukup banyak kapal perang asing yang terlambat terdeteksi dan terlanjur masuk ke Indonesia akibat dari kurangnya pengawasan wilayah maritim Indonesia. Konflik-konflik tersebut dapat menyebabkan perseteruan antar negara khususnya Indonesia dengan negara lain yang akhirnya dapat memanas dan memicu adanya perlawanan militer. Hal ini merupakan tugas khusus negara beserta TNI untuk menjaga keamanan dan kedaulatan pada sektor maritim dengan memberikan pertahanan wilayah berupa serangan militer menggunakan alusista yang dimiliki Indonesia kepada pihak lawan. Hal lain berkaitan dengan sumber daya alam Indonesia akhir-akhir ini juga sering terjadi masalah, yakni mengenai pencurian SDA pada sektor perairan. Dibutuhkan armada yang kuat untuk mengusir dan mencegah gangguan pihak asing agar masalah kedaulatan dapat diminimalisir. Untuk meminimalisir masalah tersebut, semua harus dibangun dengan mengunakan prinsip mensinergikan kekuatan antar seluruh instansi penyelenggara penegakan keamanan di laut. Sinergitas tersebut akan mewujudkan adanya kesatuan dalam struktur organisasi, mekanisme dan prosedur penyelenggara keamanan di laut yang dilakukan oleh para aparatnya dengan tujuan akhir adalah tegaknya kedaulatan (Sovereignity) dan hak berdaulat (Sovereign Right) sebagaimana diatur dalam UNCLOS 1982 [1].

Kendala yang juga nyata dialami Indonesia saat ini adalah, Indonesia sedikitnya membutuhkan 700 armada $\mathrm{AL}$ yang berupa kapal dengan teknologi tinggi untuk dapat mengatasi masalah pengawasan kedaulatan ini. Namun saat ini armada AL yang dimiliki Indonesia hanya berkisar 160 unit saja .Masih jauh dari kata cukup untuk dapat mempertahankan negara dan menjaga kedaulatan Indonesia.

Terobosan yang mulai dilakukan negara untuk memperbaiki masalah ini seperti pembuatan kapal perang lambung ganda sudah mulai digalakkan. Dengan teknologi ini diharapkan akan segera terbentuk armada-armada baru yang mumpuni serta dapat mengatasi masalah keamanan dan kedaulatan negara dikarenakan efisiensinya serta fungsinya yang bagus. 


\section{II.TINJAUAN PUSTAKA}

\section{A. Sistem Navigasi dan Persenjataan}

Navigasi adalah ilmu pengetahuan untuk mengetahui posisi kapal di laut dengan mengemudikan kapal secara aman dari suatu area ke area lain [2]. Sistem navigasi umumnya terdiri dari beberapa perangkat digital maupun analog. Untuk perangkat analog biasanya dilengkapi dengan atribut-atribut seperti kompas analog yang berfungsi sebagai alat penentu asal arah mata angin yang berguna sebagai acuan arah kapal. Untuk perangkat digital saat ini sudah terdapat GPS atau Global Positioning System yakni satu-satunya alat navigasi global dengan memanfaatkan satelit guna menentukan lokasi, kecepatan, arah, dan waktu yang telah beroperasi penuh di dunia [3].

Sedangkan persenjataan adalah hal penting dalam eksistensi kapal perang. Konsep Catamaran Tank Boatini, dilengkapi meriam $105 \mathrm{~mm}$ dengan jangkauan $5 \mathrm{~km}$ untuk direct hit dan $10 \mathrm{~km}$ untuk tembakan tak langsung. Meriam ini juga bisa memuat Anti-Tank Guided Missile Falarick. Selain itu Catamaran Tank Boat juga dibekali dengan sistem persenjataan lain seperti remote control weapon system (RCWS) dengan kaliber 7,62 mm dengan sistem nadir dan navigasi canggih untuk melumpuhkan musuh [4].

\section{B. Turbojet}

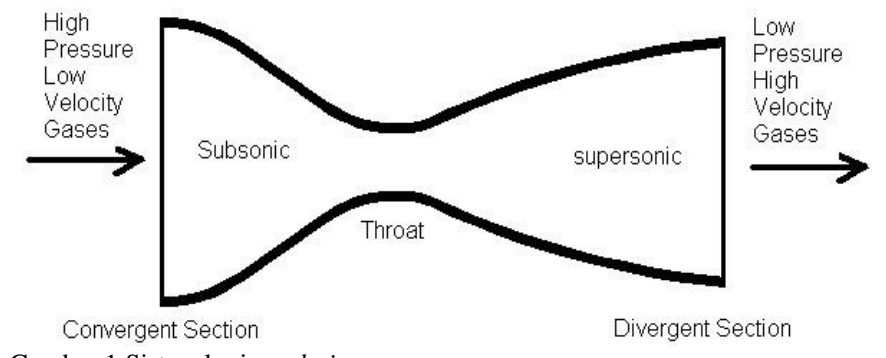

Gambar 1 Sistem kerja turbojet.

Mesin turbojet atau yang dikenal sebagai mesin turbin gas juga dikembangkan tidak hanya untuk pesawat terbang, namun juga untuk penggerak kapal dan di darat, serta untuk kendaraan terutama kendaraan berat seperti tank dan mesinmesin pembangkit listrik juga mesin untuk industri. Jenisjenis turbojet yakni turbojet dengan turbofan yang tenaganya berasal dari massa udara yang dipercepat, serta hasil pembakaran yang menuju ke satu arah sehingga mendorong mesin dan body ke arah yang berlawanan [4]. Jenis turbojet yang lain adalah turboprop dan turboshaft yang cara kerjanya berbeda dengan turbofan yakni dengan cara energi gas panasnya digunakan untuk memutar/ menggerakkan turbin yang disambungkan dengan baling-baling atau dengan sebutan lain power output shaft.

Mesin turbojet merupakan jenis mesin jet yang paling sederhana, mesin ini biasanya dipakai untuk pesawat-pesawat berkecepatan tinggi. Contoh dari mesin jet adalah mesin Rolls-Royce Olympus 593 yakni sebagai pendorong utama pesawat Concorde. Versi lain adalah mesin Marine Olympus yang memilik kemampuan $28.000 \mathrm{hp}$ (daya kuda atau setara dengan $21 \mathrm{MW}$ ) yang digunakan sebagai penggerak kapal perang modern dengan bobot mati 20.000 ton dengan kemampuan operasi berkecepatan tinggi.

Mesin dengan rekasi jet sederhana kemudian dikembangkan menjadi twin-spool low by pass ratio turbojet. Kini dari turbojet low by-pass ratio, berkembang menjadi triple-spool front fan high by-pass ratio turbojet atau yang lebih dikenal sebagai high bypass turbofan dan fanjet. Sedangkan yang masih berupa konsep adalah mesin propfan dan UDF (unducted fan) dan contra rotating-fan .

\section{Pemilihan Main Engine dan Sistem Kemudi}

Dengan menghitung hambatan yang dihasilkan oleh kapal, desainer dapat menentukan kapasitas mesin yang diperlukan oleh kapal untuk melawan hambatan tersebut sehingga kapal mampu berlayar dengan kecepatan yang telah ditentukan di awal. Maka dari itu, nilai Break Horse Power $\left(\mathrm{BHP} / \mathrm{P}_{\mathrm{B}}\right)$ yang dihasilkan oleh kapal harus dihitung..Namun, sebelum itu nilai Effective Horse Power $\left(\mathrm{EHP} / \mathrm{P}_{\mathrm{E}}\right)$, Thrust Horse Power $\left(\mathrm{THP} / \mathrm{P}_{\mathrm{T}}\right)$ dan Delivered Horse Power $\left(\mathrm{DHP} / \mathrm{P}_{\mathrm{D}}\right)$ dan nilai-nilai efisiensi harus didapat terlebih dahulu. Dikarenakan kapal menggunakan mesin turbojet, efisiensi lambung di abaikan karena di bawah air tidak ada satu barangpun yang tercelup air.

Untuk sistem berbeloknya kapal, dengan memanfaatkan thrust reverser dan thrust vectoring kapal dapat berbelok secara dinamis dan dapat berhenti secara cepat. Turbojet yang banyak digunakan pada pesawat jet menggunakan sitem ini dengan cara membalikkan arah thrust yang awalnya mengarah ke belakang berubah menuju arah depan atau samping. Dengan sistem hidrolis, kapal menkontrol pergerakan thrust vectoring dari dalam navigasi kapal sehingga kapal dapat bermanuver.

\section{Operational Requirement}

Operational requirement catamaran tank boat yang akan dirancang untuk memenuhi kebutuhan militer, mempertimbangkan beberapa faktor sebagai berikut [5] :

1. Fungsi dan Tugas

2. Wilayah Operasional kapal

3. Kecepatan kapal

4. Kemampuan Operasional kapal

\section{E. Tinjauan Wilayah}

Sesuai dengan Pasal 2, Pasal 34, Pasal 47 dan Pasal 49 UNCLOS 1982, diterangkan bahwa sebuah negara merdeka berpantai maka Negara tersebut harus berkuasa atas wilayah darat dan wilayah perairan serta udara diatasnya. Dari sekian banyak ketentuan yang disebutkan dalam UNCLOS 82 adalah pengaturan mengenai selat yang mungkin ada dalam negara merdeka, akan tetapi disisi lain, UNCLOS 82 memberikan batasan-batasan dalam menetapkan batas perairan yang dihitung dari mana dan sejauh mana sehingga tidak merugikan negara tetangga serta negara tidak berpantai. Oleh karena itu negara memiliki wewenang. Batasan-batasan tersebut perlu adanya penjagaan secara tegas terhadap pelanggar dan interfensi negara lain. Pelanggar-pelanggar tersebut juga sangat berpotensi mengganggu kedaulatan Indonesia dalam sektor pertahanan. Tidak menutup 
kemungkinan akan ada serangan militer negara lain ke Indonesia untuk menjatuhkan Indonesia apabila ada permasalahan yang tidak bisa diselesaikan dengan mufakat. Sebelum itu untuk memata-matai dan mencari informasi tentang pertahanan hingga kekuatan militer Indonesia kapal asing akan melakukan cara apapun untuk mendapatkan apa yang mereka cari termasuk mendekat ke wilayah Indonesia untuk mencari data kekuatan militer Indonesia. Untuk mengatasi masalah tersebut maka wilayah NKRI khususnya seluruh wilayah perairan Indonesia memerlukan armada militer yang kuat dan canggih untuk menjaga dan memberikan perlawanan apabila diperlukan.

Selain itu, hampir di seluruh wilayah perairan Indonesia memiliki berbagai macam sumber daya alam yang melimpah. Hal ini menimbulkan banyaknya pihak-pihak asing/luar yang secara sengaja ataupun tidak mengambil dan mengeksploitasi sumber daya alam yang berada di dalam wilayah Indonesia ini. Sebagaimana dilansir oleh BNPB bahwa laut Sulawesi akhir-akhir ini mengalami peningkatan aktifitas pembajakan yang tak hanya merampok kapal nelayan kecil, namun juga kapal komersil lainnya. Tak hanya itu, di dalam daerah Laut Sulawesi terdapat area minyak yang sangat melimpah sehingga sering terjadi gesekan antara kedua Negara antara Indonesia dengan Malaysia. Area minyak tersebut adalah area Ambalat, yang memiliki luas mencakup 15.235 kilometer persegi yang terletak di Laut Sulawesi atau Selat Makassar dan berada di dekat perpanjangan perbatasan darat antara Sabah, Malaysia, dan Kalimantan Timur, Indonesia. Ambalat merupakan area negara Indonesia sebagai Negara kepulauan. Hal ini dapat dibuktikan dengan ditandatanganinya Perjanjian Tapal Batas Kontinen Indonesia-Malaysia pada tanggal 27 Oktober 1969, yang ditandatangani di Kuala Lumpur Malaysia, telah diratifikasi pada tanggal 7 November 1969 [6]. Aster Blok Ambalat diindikasi mengandung cadangan minyak yang cukup banyak. Area yang saat ini dikelola perusahaan minyak dan gas bumi asal Italia ENI ini ternyata mampu berproduksi sekitar 30.000-40.000 barel minyak perhari. Hal ini terindikasi setelah dilakukannya pengeboran terhadap lima sumur. Menteri Energi dan Sumber Daya Mineral (ESDM) menegaskan bahwa, Area Ambalat merupakan bagian dari wilayah Negara Kesatuan Republik Indonesia (NKRI).

Hal ini yang membuat Kapal Tank Boat direncanakan akan di operasikan di seluruh wilayah perairan Indonesia khususnya di wilayah ZTE.

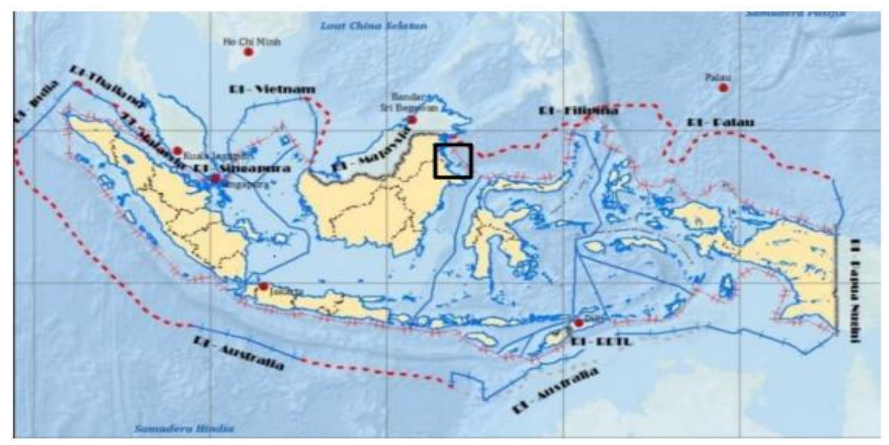

Gambar 2. Wilayah ZTE Indonesia.

\section{METODOLOGI}

\section{A. Bagan Alir}

Gambar 3 berikut merupakan Bagan alir dari metodologi pengerjaan Studi ini:

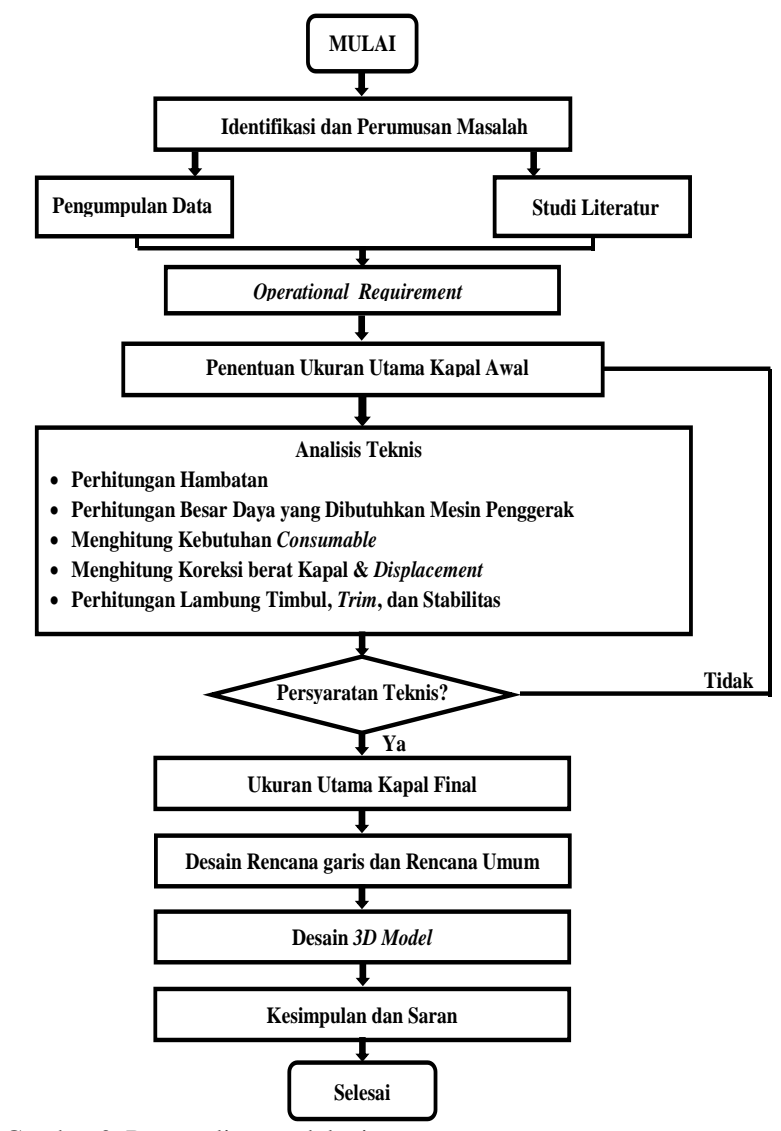

Gambar 3. Bagan alir metodologi.

\section{B. Identifikasi dan Perumusan Masalah}

Tahap awal yang dilakukan adalah identifikasi dan perumusan masalah terhadap obyek yang dijadikan Studi ini. Pada tahap awal ini dilakukan identifikasi permasalahan berupa: 1. Kemajuan teknologi alusista yang semakin canggih di bidang maritim 2 . Banyaknya pelanggaran yang terjadi di wilayah Laut Teritorial Indonesia. 3. Kurangnya kapal perang Indonesia untuk menjaga wilayah perairan. Kemudian dari hasil identifikasi tersebut, langkah selanjutnya adalah merumuskan masalah dari masalah yang telah diperoleh. Fungsi dari perumusan masalah adalah agar penyelesaian dari masalah yang dibahas menjadi jelas.

\section{Pengumpulan Data dan Studi Literatur}

Pengumpulan data yang dimaksud adalah semua data acuan yang digunakan untuk menunjang desain kapal Tank Boat. Data yang dibutuhkan yakni data referensi kapal perang katamaran dari buku dan browsing internet yang diperlukan dalam proses pemodelan Studi. Data yang diperlukan seperti dimensi utama, fungsi senjata, dan lain lain. Selain mengumpulkan data, pengumpulan studi literatur juga dilakukan guna memperkuat teori yang dipakai. Studi literatur dilakukan untuk mendapatkan pengetahuan dan teori-teori yang terkait dengan Studi ini. Studi ini bertujuan 
untuk memahami permasalahan yang ada, sehingga dapat memunculkan hipotesis awal yang selanjutnya bisa disusun menjadi hipotesa awal. Studi literatur yang dilakukan adalah berkaitan dengan hal sebagai berikut :

1. Cara Kerja Kapal Tank Boat

Perlu untuk diketahui bagaimana proses kerja kapal tank boat dapat beroperasi dan bagaimana alur operasinya

2. Metode Desain kapal

Terdapat beberapa metode dalam proses mendesain kapal yang perlu diketahui dan dipahami serta dapat dijadikan sebagai pertimbangan dalam pemilihan metode yang sesuai.

3. Persenjataan

Perlu untuk diketahui peralatan perang apa saja yang mendukung desain Catamaran Tank Boat ini.

\section{Penentuan Operational Requirement}

Setelah berbagai data dan studi literatur ditemukan, maka tahap selanjutnya adalah penentuan Operational Requirements dan Payload Catamaran Tank Boat. Operational Requirements dilakukan untuk menentukan kebutuhan operasional dari Catamaran Tank Boat dalam melaksanakan tugasnya menjaga kedaulatan wilayah maritim Indonesia. Kebutuhan operasional tersebut termasuk kebutuhan peralatan pendukung kapal. Operational Requirements tersebut dapat digunakan dalam menentukan Payload (muatan) pada catamaran tank boat

\section{E. Penentuan Ukuran Utama Awal dan Ruang Muat}

Setelah Operational Requirements dan Payload ditentukan, tahap selanjutnya adalah menentukan ukuran utama awal dan kapasitas ruang muat. Penentuan ukuran utama dilakukan dengan metode Parent design approach. Parent Design Approach adalah salah satu metode desain kapal dengan perbandingan atau komparasi, yaitu dengan cara mengambil sebuah kapal yang dijadikan sebagai acuan yang memiliki karakteristik sama dengan kapal yang akan dirancang. Dalam hal ini, desainer sudah memiliki referensi kapal yang sama dengan kapal yang akan dirancang nantinya. Untuk penentuan kapasitas muatan akan dijabarkan pada Bab IV. Ukuran utama awal ini bersifat sementara yang nantinya akan dilakukan optimisasi berdasarkan peninjauan pada banyak hal dalam perhitungan teknis. Layout awal kapal juga dipersiapkan supaya mempermudah menentukan posisi payload yang akan di letakkan pada kapal.

\section{F. Analisis Teknis}

Analisis teknis dilakukan sesuai dengan studi literatur yang telah dipelajari. Hal itu meliputi perhitungan hambatan kapal, perhitungan daya yang dibutuhkan kapal, penentuan mesin, perhitungan berat kapal, perhitungan stabilitas, perhitungan trim dan perhitungan lambung timbul.

\section{G. Desain Lines Plan, Rencana Umum, dan 3D Model}

Dalam pembuatan Rencana Garis kapal, dilakukan dengan bantuan software Maxsurf Education Version. Dari desain yang telah dibuat di Maxsurf Education Version diperoleh Lines Plan kapal. Kemudian untuk memperhalus
Lines Plan, dilakukan perbaikan pada software CAD. Sedangkan untuk pembuatan general arrangement, dilakukan setelah Lines Plan selesai. Hal ini dikarenakan garis besar dari General Arrangement diambil dari Lines Plan. Pembuatan General Arrangemen dilakukan dengan menggunakan software CAD. Pembuatan General Arrangement mengacu pada General Arrangement kapal konsep Lundin Antasena X-18.

\section{H. Kesimpulan}

Tahap akhir dalam penelitian ini adalah penarikan kesimpulan. Kesimpulan yang ditarik sebisa mungkin dapat menjawab tujuan yang ada pada Studi ini, meliputi penentuan ukuran utama Tank Boat, sistem propulsi dan kemudi yang sesuai untuk operasi kapal, gambar Lines Plan, General Arrangement, dan pemodelan 3D.

\section{ANALISIS TEKNIS}

\section{A. Analisis Perhitungan Ruang Muat dan Ukuran Utama} Kapal Awal

Perhitungan ruang muat dilakukan berdasarkan platform yang direncanakan untuk operasi kapal. Platform tersebut dijabarkan pada tabel 1 di bawah :

Tabel 1. Platform kapal

\begin{tabular}{|c|c|c|c|c|}
\hline No. & Komponen & Jumlah & $\begin{array}{c}\text { Dimensi L X B X } \\
\text { H (mm) }\end{array}$ & Berat $(\mathrm{Kg})$ \\
\hline 1 & $\begin{array}{c}\text { Main } \\
\text { Engine }\end{array}$ & 1 & $6000 \times 1330$ & 2300 \\
\hline 2 & $\begin{array}{l}\text { Thermal } \\
\text { Camera }\end{array}$ & 1 & $300 \times 50 \times 30$ & 30 \\
\hline 3 & $\begin{array}{l}\text { CT-CV } \\
\text { Turret }\end{array}$ & 1 & $12 \mathrm{~m}$ & 4000 \\
\hline 4 & life raft & 2 & $900 \times 550 \times 380$ & 56 \\
\hline 5 & Lemur & 1 & $\mathrm{H}=850, \mathrm{D}=870$ & 270 \\
\hline 6 & $\begin{array}{l}\text { Turret } \\
\text { Ammo }\end{array}$ & 12 & $1015 \times 105$ & 300 \\
\hline 7 & $\begin{array}{l}\text { Lemur } \\
\text { Ammo }\end{array}$ & 300 & 12.7 & 50 \\
\hline 8 & $\begin{array}{c}\text { Navigation } \\
\text { Bridge } \\
\text { system }\end{array}$ & 1 & $\begin{array}{l}\text { Sesuai pada } \\
\text { spesifikasi }\end{array}$ & 250 \\
\hline 9 & RGB & 1 & $\begin{array}{c}\mathrm{P}=7800, \mathrm{~W}= \\
2500\end{array}$ & 450 \\
\hline 10 & $\begin{array}{c}12 \mathrm{~V} \\
\text { Battery }\end{array}$ & 4 & $578 \times 254 \times 219$ & 100 \\
\hline 13 & $\begin{array}{c}\text { Thrust } \\
\text { vectoring }\end{array}$ & 1 & $\begin{array}{l}\text { Sesuai mesin } \\
\text { Turbojet }\end{array}$ & 200 \\
\hline 15 & $\mathrm{AE}$ & 2 & $1029 \times 629 \times 251$ & 824 \\
\hline 16 & Fresh Water & 2 & Sesuai GA & 100 \\
\hline 17 & Fuel oil & 10 & Sesuai GA & 14271,32 \\
\hline 18 & Diesel oil & 2 & Sesuai GA & 428 \\
\hline 19 & Crew & 4 & - & 360 \\
\hline \multicolumn{2}{|c|}{ BERAT TOTAL } & & & 23989,4 \\
\hline
\end{tabular}

Seluruh bagian platform harus dapat ditampung pada kapal. Luasan kapal harus dapat menampung seluruh platform pada posisi masing-masing. Sedangkan ukuran utama awal kapal diperoleh dari metode Parent design approach. Parent Design Approach adalah salah satu metode mendesain kapal dengan cara perbandingan atau komparasi, yaitu dengan cara mengambil sebuah kapal yang dijadikan 
sebagai referensi yang memiliki karakteristik sama dengan kapal yang akan dirancang. Dalam hal ini desainer sudah memiliki referensi kapal yang sama dengan kapal yang akan dirancang.

\section{B. Pembuatan Layout Awal}

Tahapan selanjutnya setelah memperoleh ukuran utama awal kapal adalah pembuatan layout awal. Pembuatan layout awal ditujukan untuk mengetahui gambaran awal desain kapal. Dengan adanya layout awal desainer akan menemukan ukuran awal serta koefisien-koefisien yang diperlukan untuk perhitungan selanjutnya. Layout awal dibuat dengan menggunakan software maxsurf modeller.

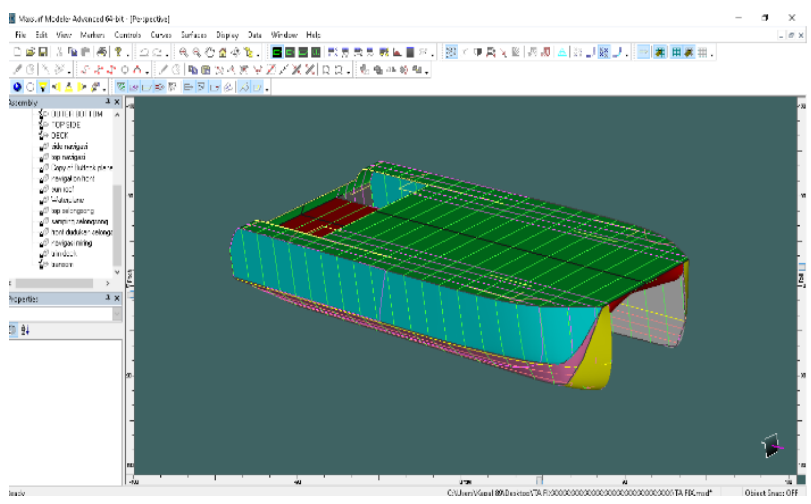

Gambar 4. Layout awal tank boat

Setelah Layout awal dibuat, dilakukan perhitungan koefisien dengan software maxsurf. Hasil perhitungan koefisien-koefisien dijabarkan pada tabel di bawah:

Tabel 2.

Main coefficient

\begin{tabular}{cc}
\hline \hline Main Coefficient & Nilai \\
\hline Block Coefficient $\left(\mathrm{C}_{\mathrm{b}}\right)$ & 0,59 \\
Midship Coefficient $\left(\mathrm{C}_{\mathrm{m}}\right)$ & 0,653 \\
Waterplane Coefficient $\left(\mathrm{C}_{\mathrm{wp}}\right)$ & 0,918 \\
Prismatic Coefficient $\left(\mathrm{C}_{\mathrm{p}}\right)$ & 0,904 \\
\hline \hline
\end{tabular}

\section{Perhitungan Hambatan dan Pemilihan Mesin}

Tahapan selanjutnya, dilakukan perhitungan hambatan Kapal dan daya yang dibutuhkan kapal. Hambatan digunakan untuk menentukan daya mesin induk yang diperlukan untuk mendorong kapal nantinya. Dengan software maxsurf, ditemukan hambatan kapal pada kecepatan dinas 45knot seperti dilihat pada Tabel 3:

Tabel 3.

Hasil perhitungan hambatan kapal 1 lambung

\begin{tabular}{cccccc}
\hline \hline No. & $\begin{array}{c}\text { Speed } \\
(\mathrm{kn})\end{array}$ & Fn Lwl & Fn Vol. & $\begin{array}{l}\text { savitsky } \\
\text { planning } \\
(\mathrm{kN})\end{array}$ & $\begin{array}{l}\text { savitsky } \\
\text { planning } \\
(\text { Watt })\end{array}$ \\
11 & 25,000 & 1,001 & 2,604 & 16,8 & 254,317 \\
19 & 45,000 & 1,801 & 4,687 & 33,9 & 924,203 \\
23 & 55,000 & 2,202 & 5,729 & 41,8 & $1,390,639$ \\
\hline \hline
\end{tabular}

Dilanjutkan dengan pengecekan kondisi trim kapal dan freeboard sesuai peraturan NCVS serta akumulasi hambatan total kapal (2 lambung) sebagai acuan pemilihan mesin induk.

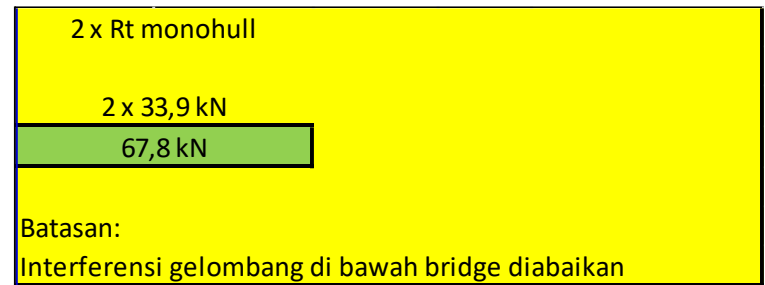

Gambar 5. Hambatan 2 lambung.

Dengan ditemukannya hambatan total kapal, beberapa koefisien dan efsiensi serta tambahan koreksi daerah pelayaran ,daya mesin utama dapat ditentukan sesuai dengan kebutuhan. Mesin yang diambil adalah produk GE-YJ93 $98 \mathrm{kN}$ Thrust seperti pada Gambar 6.

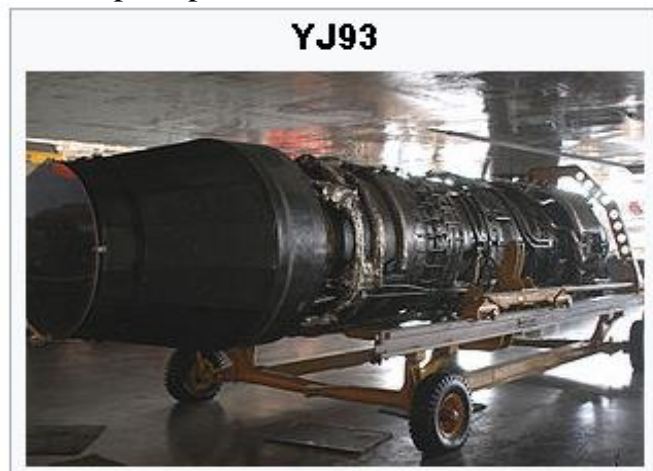

YJ93-GE-3 engine at National Museum of the United States Air Force

\begin{tabular}{ll}
\hline Type & Turbojet \\
National origin & United States \\
Manufacturer & General Electric Aircraft Engines \\
Major applications & North American XB-70 Valkyrie \\
Developed into & General Electric GE4
\end{tabular}

Gambar 6. Mesin turbojet Yj-93

\section{Ukuran Utama Catamaran Tank Boat}

Setelah seluruh analisis teknis dilakukan, tahap selanjutnya adalah penentuan ukuran utama.Dari sekian banyak perhitungan teknis yang telah dilakukan, ditentukan ukuran utama akhir sebagai ukuran utama kapal Tank Boat

Tabel 4

Ukuran utama kapal

\begin{tabular}{cc}
\hline \hline Ukuran Utama & Nilai \\
\hline Panjang Keseluruhan (Loa) & $18 \mathrm{~m}$ \\
Panjang antara Dua Garis Tegak $\left(\mathrm{L}_{\mathrm{pp}}\right)$ & $17,03 \mathrm{~m}$ \\
Lebar $(\mathrm{B})$ & $6,60 \mathrm{~m}$ \\
Tinggi $(\mathrm{H})$ & $2,80 \mathrm{~m}$ \\
Sarat $(\mathrm{T})$ & $1,00 \mathrm{~m}$ \\
\hline \hline
\end{tabular}

Ukuran utama diatas telah memenuhi rasio insel and molland sebagai acuan desain kapal katamaran. Freeboard, trim, dan stabilitas kapal juga sudah memenuhi persyaratan dari NCVS dan HSC Annex 7 intact stability.

\section{E. Desain Rencana Garis (Lines Plan)}

Tahapan selanjutnya dilakukan pembuatan Rencana Garis Kapal menggunakan software maxsurf dan software CAD. Gambar 7 merupakan Rencana Garis Kapal. 


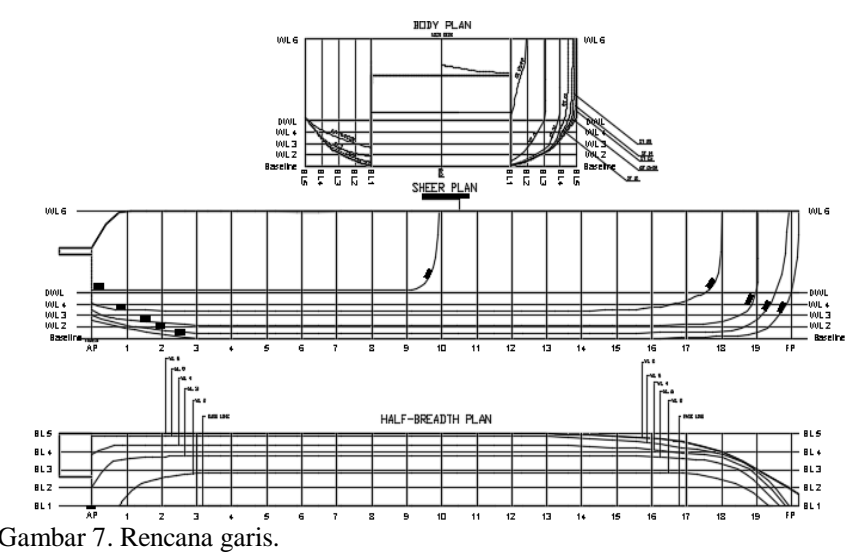

\section{F. Desain Rencana Umum}

Rencana umum/ General Arrangement didefinisikan sebagai gambar perencanaan dan peletakan ruang untuk semua kebutuhan dan perlengkapan kapal sesuai posisi dan akses yang diperlukan. Gambar rencana umum dibuat berdasarkan rencana garis yang telah dibuat sebelumnya sehingga perencanaan dan pembagian ruangan dalam rencana umum lebih mudah sesuai dengan fungsinya masingmasing. Rencana Umum Kapal dapat dilihat pada Gambar 8

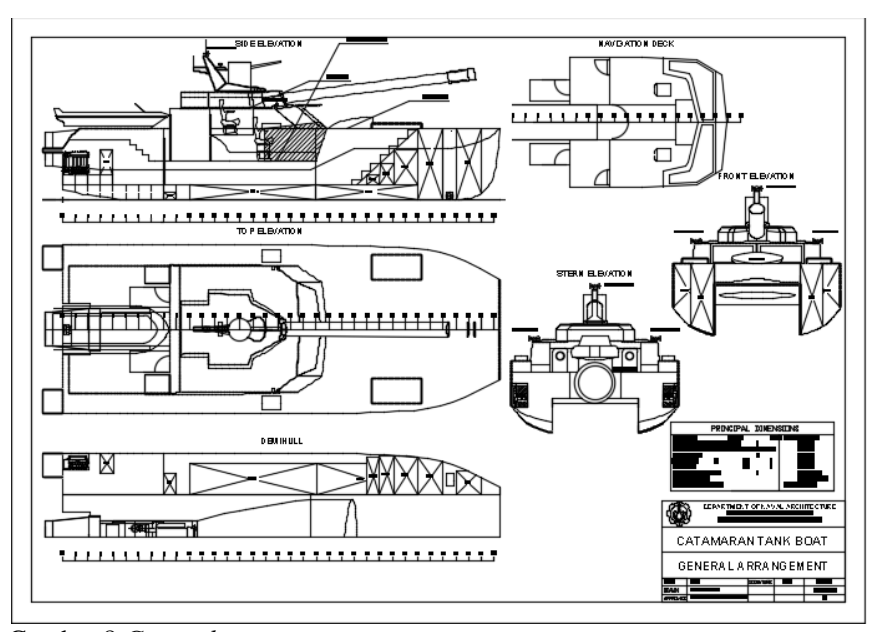

Gambar 8.General rrrangement.

\section{G. Desain Model 3D}

Pemodelan 3D Tank Boat menggunakan bantuan software maxsurf. Hasil 3D dapat dilihat pada Gambar 9,10

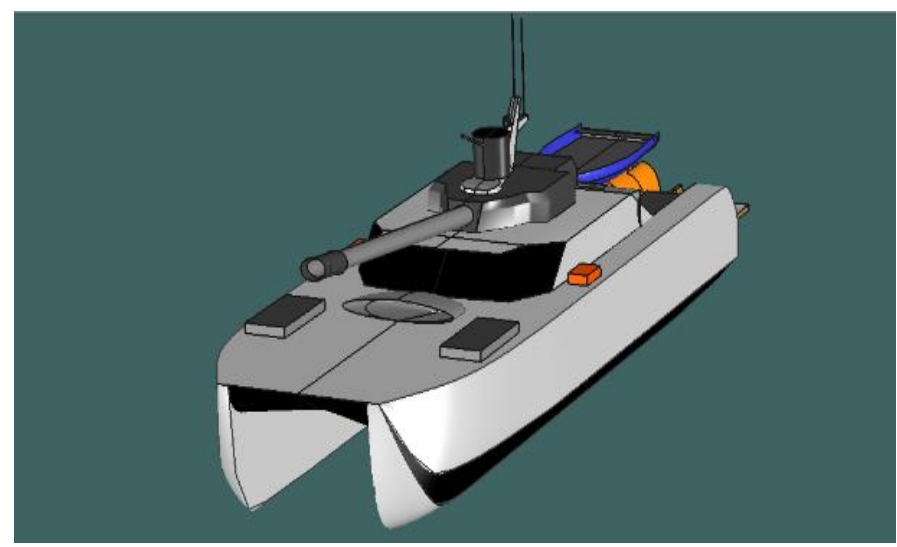

Gambar 9. Desain 3D front.

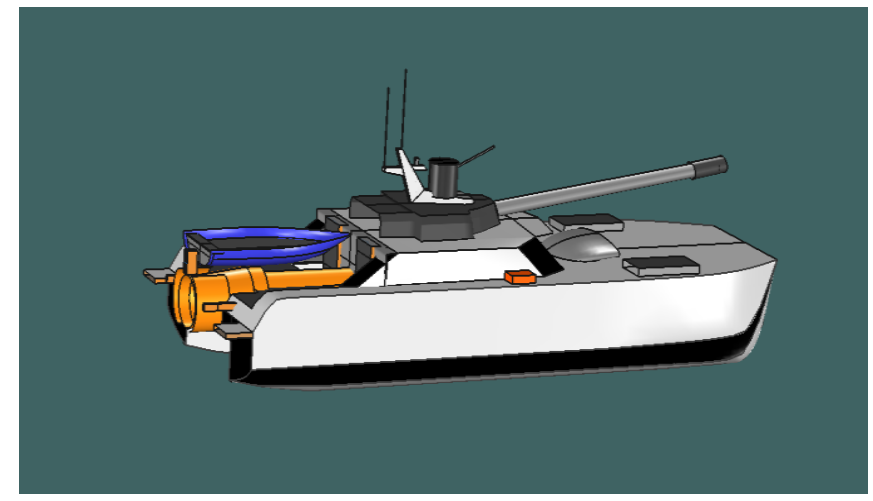

Gambar 10. Desain 3D side.

\section{KESIMPULAN}

Setelah dilakukan penelitian, kesimpulan yang dapat di tarik dari Studi ini adalah sebagai berikut:

1. Didapatkan operational requirement dari rancangan kapal Catamaran Tank untuk memenuhi kebutuhan dalam beroperasi, mempertimbangkan beberapa faktor, sebagai berikut:

Fungsi dan tugas :

a. Divisi FPB sebagai armada pemukul bantu dalam fungsi pertahanan wilayah maritim Indonesia.

b. Patroli pemantauan dan pengamanan wilayah maritim Indonesia

Wilayah operasional :

a. Seluruh perairan Indonesia khususnya ZTE

Kecepatan :

a. Kecepatan maksimal yang dapat dicapai adalah 55 knot

b. Kecepatan operasi 25-45 knot

Kemampuan operasional :

a. Dalam operasi pengejaran dan perlawanan terhadap musuh, kecepatan kapal dapat mencapai 55 knot dengan endurance selama 148 menit.

b. Dalam operasi pengejaran dan perlawanan terhadap musuh, kecepatan kapal yang direncanakan adalah 45 knot, maka endurance kapal yakni 154 menit.

Dalam misi patroli, kapal dapat beroperasi selama 6,5 jam.

2. Ukuran Utama desain Kapal Catamaran Tank Boat yang yaitu :

$\begin{array}{lll}\text { LOA } & =18 & \mathrm{~m} \\ \text { Lpp (Panjang) } & =17.03 & \mathrm{~m} \\ \mathrm{~B}(\text { Lebar) } & =6.6 & \mathrm{~m} \\ \mathrm{H} \text { (Tinggi) } & =2.8 & \mathrm{~m} \\ \mathrm{~T} \text { (Sarat) } & =1 & \mathrm{~m}\end{array}$

Perhitungan teknis yang dilakukan telah memenuhi.

a. Perhitungan berat yang telah dilakukan menunjukkan margin berat sebesar $3.8 \%$. Displacement kapal diketahui sebesar 31.94 ton dan berat kapal (LWT+DWT) adalah 30.737 ton pada muatan penuh. Sehingga perhitungan berat diterima.

b. Perhitungan trim yang telah dilakukan menghasilkan hasil $-0.326 \mathrm{~m}, 0,296 \mathrm{~m},-0,271 \mathrm{~m}$, dan $0,032 \mathrm{~m}$, sedangkan batasan trim maksimal adalah sebesar 0.34 m. Sehingga perhitungan trim telah memenuhi. 
c. Perhitungan lambung timbul yang telah dilakukan menunjukkan batasan lambung timbul minimal sebesar $0.47 \mathrm{~m}$, sedangkan lambung timbul kapal sebenarnya adalah $1.8 \mathrm{~m}$. Sehingga perhitungan lambung timbul diterima.

d. Perhitungan stabilitas yang dilakukan menggunakan acuan regulasi dari HSC Annex 7 intact stability Code 2000. Hasil yang didapatkan semua parameter stabilitas telah terpenuhi.

\section{DAFTAR PUSTAKA}

[1] A. Soedewo, "Pemberlakuan Ketentuan Bagi Kapal Berbendera Asing Untuk Melintas Di Alur Laut Kepulauan Indonesia (ALKI) II Ditinjau dari Perspektif Hukum Negara Indonesia dan United Nation Convention On The Law Of The Sea 1982 (UNCLOS)," 2015.

[2] S. R. M. Jerry Jeliandra Suja, Sulistiyanti and M. Komarudin, "Sistem Navigasi pada Unmanned Surface Vehicle untuk Pemantauan Daerah Perairan," J. Rekayasa dan Teknol. Elektro, vol. 34, 2017.

[3] W. Habibi and Mazharuddin S, "Pembangunan Sistem Pelacakan dan Penelusuran Device Mobile Berbasis Global Positioning Sistem (GPS) pada Platform Mobile Google," 2011.

[4] Sukadana, "Teori Turbin Gas dan Jet Propulsi," Bali, 2015

[5] B. G. P. Putra, "Studi Desain Midget Submarine untuk Aplikasi Intelijen dan Monitoring Perairan Indonesia," J. Publ. Ilm. Online Mhs. ITS, vol. 5, no. 1, 2015.

[6] D. Hardianto, "Studi Pembuatan Konsep Desain Unmanned Surface Vehicle (USV) untuk Monitoring Wilayah Perairan Indonesia," Surabaya, 2017. 